\title{
Aerosol loading in the Southeastern United States: reconciling surface and satellite observations
}

\author{
B. Ford ${ }^{1}$ and C. L. Heald ${ }^{2}$ \\ ${ }^{1}$ Department of Atmospheric Science, Colorado State University, Fort Collins, CO, USA \\ ${ }^{2}$ Department of Civil and Environmental Engineering and Department of Earth, Atmospheric and Planetary Sciences, MIT, \\ Cambridge, MA, USA
}

Correspondence to: B. Ford (bonne@atmos.colostate.edu)

Received: 25 February 2013 - Published in Atmos. Chem. Phys. Discuss.: 15 April 2013

Revised: 6 July 2013 - Accepted: 28 July 2013 - Published: 16 September 2013

\begin{abstract}
We investigate the seasonality in aerosols over the Southeastern United States using observations from several satellite instruments (MODIS, MISR, CALIOP) and surface network sites (IMPROVE, SEARCH, AERONET). We find that the strong summertime enhancement in satelliteobserved aerosol optical depth (AOD) (factor 2-3 enhancement over wintertime AOD) is not present in surface mass concentrations (25-55\% summertime enhancement). Goldstein et al. (2009) previously attributed this seasonality in AOD to biogenic organic aerosol; however, surface observations show that organic aerosol only accounts for $\sim 35 \%$ of fine particulate matter (smaller than $2.5 \mu \mathrm{m}$ in aerodynamic diameter, $\mathrm{PM}_{2.5}$ ) and exhibits similar seasonality to total surface $\mathrm{PM}_{2.5}$. The GEOS-Chem model generally reproduces these surface aerosol measurements, but underrepresents the AOD seasonality observed by satellites. We show that seasonal differences in water uptake cannot sufficiently explain the magnitude of AOD increase. As CALIOP profiles indicate the presence of additional aerosol in the lower troposphere (below $700 \mathrm{hPa}$ ), which cannot be explained by vertical mixing, we conclude that the discrepancy is due to a missing source of aerosols above the surface layer in summer.
\end{abstract}

\section{Introduction}

Portmann et al. (2009) suggest that increases in atmospheric aerosols of biogenic origin associated with regional reforestation may have caused cooling over the Southeastern United States (SEUS) in recent decades. This theory is supported by the strong winter-to-summer seasonality in satellite-derived aerosol optical depth (AOD) that spatially and temporally matches biogenic volatile organic compound (BVOC) emissions in the region (Goldstein et al., 2009). A potential source of this summertime aerosol could be enhanced production of secondary organic aerosols (SOA) formed by the oxidation of volatile organic compounds (VOC) emitted from vegetation in the presence of anthropogenic pollutants from urban areas (Volkamer et al., 2006; Hoyle et al., 2011). The SEUS could be particularly susceptible to such an effect (Weber et al., 2007), which could augment summertime aerosol loading in the region.

The SEUS is densely forested and primarily a rural environment, although there are also several major urban centers in the region. Previous studies have shown that the fine particulate matter (smaller than $2.5 \mu \mathrm{m}$ in aerodynamic diameter, $\mathrm{PM}_{2.5}$ ) in the region is dominated by ammonium sulfate and organic matter (OM), which together account for 60 $90 \%$ of the surface $\mathrm{PM}_{2.5}$ concentrations (Edgerton et al., 2005; Weber et al., 2007; Hand et al., 2012; Zhang et al., 2012). Throughout most of the year, organic carbon is produced from wood combustion and diesel exhaust; while secondary production dominates in the summertime (Zheng et al., 2002). Lim and Turpin (2002) suggest that SOA generally makes up half of the measured organic carbon. Although urban centers often have higher $\mathrm{PM}_{2.5}$ concentrations and their emissions can have a regional impact, water-soluble organic carbon concentrations, which are often used as a marker for SOA, appear to have a more widespread homogenous source over the region (Peltier et al., 2007).

Several studies have also suggested that aerosol loading over the Southeastern US has decreased over the last decade. 
Edgerton et al. (2005) note a 15-20\% decrease in surface $\mathrm{PM}_{2.5}$ mass in the region over the five-year period from 1999-2003, mainly attributable to declines in sulfate and organic matter. Using satellite measurements of AOD and surface $\mathrm{PM}_{2.5}$ measurements over Georgia, Alston et al. (2012) also suggest that aerosol loading over the Southeastern US declined from 2000-2009. Additionally, Leibensperger et al. (2012) suggest that anthropogenic aerosols are responsible for regional cooling over the Eastern US over the last century but that this radiative forcing has declined since 1990 mainly due to decreases in domestic emissions of sulfur dioxide. However, given limitations in both our measurement and understanding of BVOC emissions and SOA formation (Hallquist et al., 2009), it is unclear whether biogenic emissions, and the aerosols produced upon oxidation of these emissions, have also changed over this same time period. The evolution of these biogenic emissions is difficult to predict (e.g., Heald et al., 2009), representing a significant hurdle for future air quality management efforts and the prediction of climate forcing.

In this study, we use a suite of satellite and surface observations with a global model to explore the origin of the observed enhancement of summertime AOD in the SEUS. We aim to provide insight relevant to the Southeastern Atmosphere Study (SAS) campaign in 2013, whose primary objective is to investigate the impact of biogenic aerosol on regional climate and air quality.

\section{Description of observations and model}

\subsection{Satellite observations}

For this study, we use a variety of satellite instruments and products to analyze aerosol and cloud distributions and variability along with fire activity.

The Multi-angle Imaging SpectroRadiometer (MISR) instrument was launched into sun-synchronous orbit aboard the EOS-Terra satellite in 1999 and provides global measurements of AOD with an equator crossing of $\sim 10: 30 \mathrm{a}$.m. local time (Diner et al., 2005; Martonchik et al., 2009). MISR employs nine different cameras to make multi-angle radiance measurements in four spectral bands (visible to nearinfrared). Here we use the Version 22 Level 3 (gridded) global aerosol product, which provides daily averaged AOD at $555 \mathrm{~nm}$ that is gridded and filtered to remove any grid boxes wherein the standard deviation of the averaged Level 2 (ungridded) AOD data is greater than 2.5 (Ridley et al., 2012).

The Moderate Resolution Imaging Spectroradiometer (MODIS) measures radiances at 36 wavelengths to characterize a variety of land and atmospheric properties. We use observations here from the MODIS instrument launched aboard the EOS-Aqua platform in 2002, which flies as part of the ATrain constellation, making simultaneous measurements at an equator crossing time of $\sim 13: 30 \mathrm{~L} T$. AOD from MODIS is retrieved separately over the ocean and land to account for differences in surface properties (e.g., Remer et al., 2005). While some studies have found a high AOD bias in the Western US due to the use of an estimated surface reflectance over the bright land surface (Drury et al., 2010), the SEUS has dense vegetation that provides good dark targets and greater confidence in the MODIS aerosol retrieval (Roy et al., 2007). For this work, we use Collection 5 Level 3 daily measurements and combine land and ocean optical depth retrievals. We filter the MODIS data to include only grid boxes with cloud fractions below 0.5 and aerosol optical depths less than 1.5. We note that the magnitude of AOD observed by MODIS is sensitive to the cloud fraction filtering (Zhang et al., 2008); however the spatial distribution and relative increase from winter to summer remain the same when cloud fraction filtering is varied from 0.1 to 0.8 . To investigate the impact of biomass burning on aerosol loading, we also examined MODIS fire counts. For this, we use V005 MODIS Aqua $1^{\circ} \times 1^{\circ}$ monthly gridded active fire counts, which have frequently been used as an estimate of biomass burning activity (Duncan et al., 2003; Zeng et al., 2008; Zhang et al., 2010).

The Cloud-Aerosol Lidar with Orthogonal Polarization (CALIOP) was launched aboard the CALIPSO satellite in 2006 as part of the A-Train constellation. The instrument detects the intensity and orthogonally polarized components of backscattered radiation at two wavelengths, $532 \mathrm{~nm}$ and $1064 \mathrm{~nm}$ (Winker et al., 2003). The details of the data processing algorithms are given by Winker et al. (2009).

Through extensive comparisons between CALIOP and the airborne NASA Langley Research Center High Spectral Resolution Lidar, Rogers et al. (2011) have demonstrated the high accuracy of CALIOP's $532 \mathrm{~nm}$ attenuated backscatter calibration, finding that total attenuated backscatter from the two instruments agrees within $2.7 \% \pm 2.1 \%$ at night and $2.9 \% \pm 3.9 \%$ during the day. Other studies have also found good agreement between CALIOP and ground-based lidar measurements (e.g., Mamouri et al., 2009; Mona et al., 2009).

A vertical profile of aerosol extinction is estimated from the measurement of backscattered radiation, but relies on a lidar ratio for the conversion (Young and Vaughan, 2009). This value can be derived from layer transmittance, or the aerosol classification scheme (which relies on the two wavelength backscatter measurements, approximate volume depolarization ratios, surface type, geographic location and layer altitude) can specify a lidar ratio based on the assumed aerosol type (Omar et al., 2009). The six aerosol types used are defined from cluster analysis of AERONET datasets (Omar et al., 2005). While the CALIOP algorithm uses the mean lidar ratio for each aerosol type, the associated standard deviations suggest that the uncertainty in these values could be $30-50 \%$. The correct classification of clouds and aerosols and selection of an appropriate lidar ratio is the largest 
source of the uncertainty in the retrieved extinction profile (Young et al., 2013).

We use the Level 2 Version $3.015 \mathrm{~km}$ Aerosol Profiles and filter the CALIOP observations using cloud aerosol distinction (CAD) scores, extinction uncertainty values, atmospheric volume descriptors, extinction quality control (QC) flags and total column optical depths. We make the approximation that all extinction observations with a corresponding atmospheric volume descriptor that indicates clear air have zero aerosol extinction. For comparisons of simulated extinction profiles with observed profiles, we match clear sky CALIOP profiles with the corresponding grid box and apply a simple detection limit to the model profile following Ford and Heald (2012). For further information on the impact of our filtering and sampling methods, we refer the reader to Ford and Heald (2012). Although the nighttime data have a greater signal-to-noise ratio (SNR) due to the lack of noise from background solar illumination (Hunt et al., 2009); in Fig. 1, we use daytime observations to coincide with the MODIS observations. For the rest of our analysis (Figs. 5 and 6), we use the more reliable nighttime profiles. Previous comparisons of seasonally averaged AOD from CALIOP show that daytime observations have only a slight low bias compared to the night observations in source and outflow regions and a slight high bias over remote marine regions (Ford and Heald, 2012). We re-grid the satellite AOD observations to a $2^{\circ} \times 2.5^{\circ}$ resolution and calculate daily averages. In order to preserve the amount of data, we do not co-sample all the data. However, co-sampling the data does not change the spatial distributions or the magnitude of seasonality reported in Sect. 3.

For seasonal cloud fraction over the SEUS, we compare observations from MODIS Aqua and MODIS Terra with observations from the CloudSat Cloud Profiling Radar. In particular, we use the CloudSat Level 2 Radar-Lidar GEOPROF product for profiles of cloud fraction and the Cloudsat Auxiliary Data to convert above-ground altitude to pressure coordinates for December 2008-2009. The GEOPROF product combines observations from both CALIOP, which is useful for observing thin cirrus clouds but is completely attenuated in deep clouds (optical depths $>3$ ), and the CloudSat Cloud Profiling Radar, which has a millimeter wavelength and is able to penetrate through most non-precipitating clouds (Stephens et al., 2002, 2008). To compare with twodimensional spatial distributions of cloud fractions observed by MODIS, we use the maximum cloud fraction from each profile observed by CloudSat/CALIOP.

\subsection{Ground-based data}

We use observations from the global AErosol RObotic NETwork (AERONET) of sun photometers in the SEUS (Holben et al., 1998). AERONET sites record AOD and aerosol properties at several wavelengths in the visible and near-infrared, and have been used for validation studies of satellite mea- surements (e.g., Remer et al., 2002). For this work, we use hourly Version 2 Level 2 measurements from the Walker Branch and University of Alabama (UA) Huntsville sites for months in 2008-2009.

We also use surface measurements of $\mathrm{PM}_{2.5}$ concentrations from both the Interagency Monitoring of Protected Visual Environments (IMPROVE) and Southeastern Aerosol Research and Characterization (SEARCH) networks. Surface measurements of atmospheric composition from the IMPROVE network are taken over a $24 \mathrm{~h}$ period once in three days and are analyzed for the concentration of fine, total, and speciated particle mass (Malm et al., 1994). Ammonium mass is determined by assuming that sulfate and nitrate are fully neutralized, which means that this is an upper bound for the dry mass of ammonium. The IMPROVE network PM $_{2.5}$ values used in this study are the reconstructed fine mass (RCFM) determined by adding the values of ammonium sulfate, ammonium nitrate, soil, sea salt, elemental carbon and organic matter. We use 1.8 as the organic carbon to organic matter multiplier following Hand et al. (2012), though we note that this could be too high or too low at specific sites as Malm and Hand (2007) have given a range of 1.2 to 2.6.

The SEARCH network is composed of eight sites consisting of pairs of urban and rural/suburban locations in four states (AL, FL, GA, MS), which all measure meteorological parameters, gas phase pollutants and major $\mathrm{PM}_{2.5} \mathrm{com}-$ ponents (organic carbon, elemental carbon, sulfate, nitrate, ammonium, and trace metals) (Hansen et al., 2003; Edgerton et al., 2005, 2006). These sites have both continuous and $24 \mathrm{~h}$ integrated filter-based measurements of $\mathrm{PM}_{2.5}$, and the sample frequency is every 3 days, except for at the sites located in Atlanta and Birmingham, which report daily. However, we sample the data from these two sites to the same measurement days as the other sites.

SEARCH network $\mathrm{PM}_{2.5}$ concentrations are calculated as the sum of sulfate, nitrate, ammonium, organic matter (using $1.8[\mathrm{OC}])$, elemental carbon, and major metal oxides (MMO). MMO is the sum of aluminum, calcium, iron, potassium, silica, and titanium in the highest oxidation state and is almost equivalent to the soil concentrations reported by the IMPROVE network. However, the soil equation used for the IMPROVE network makes corrections to account for a lower oxidation state of iron, contributions from other elements, and potassium from non-soil sources, so that [SOIL] $=(2.20[\mathrm{Al}]+2.49[\mathrm{Si}]+1.63[\mathrm{Ca}]+2.42[\mathrm{Fe}]+1.94[\mathrm{Ti}])$ (Malm et al., 1994). We also note that this standard calculation of $\mathrm{PM}_{2.5}$ for SEARCH sites does not include sea salt as included with the IMPROVE data (calculated as $1.8[\mathrm{Cl}]$ ), and chlorine has only been reported since 2009. To estimate species contributions to the total $\mathrm{PM}_{2.5}$ from the SEARCH sites, we use the assumptions for the IMPROVE measurements to include a modified soil concentration and a value for sea salt using chlorine measurements from 2009. We also use hourly measurements of total $\mathrm{PM}_{2.5}$ mass concentrations 


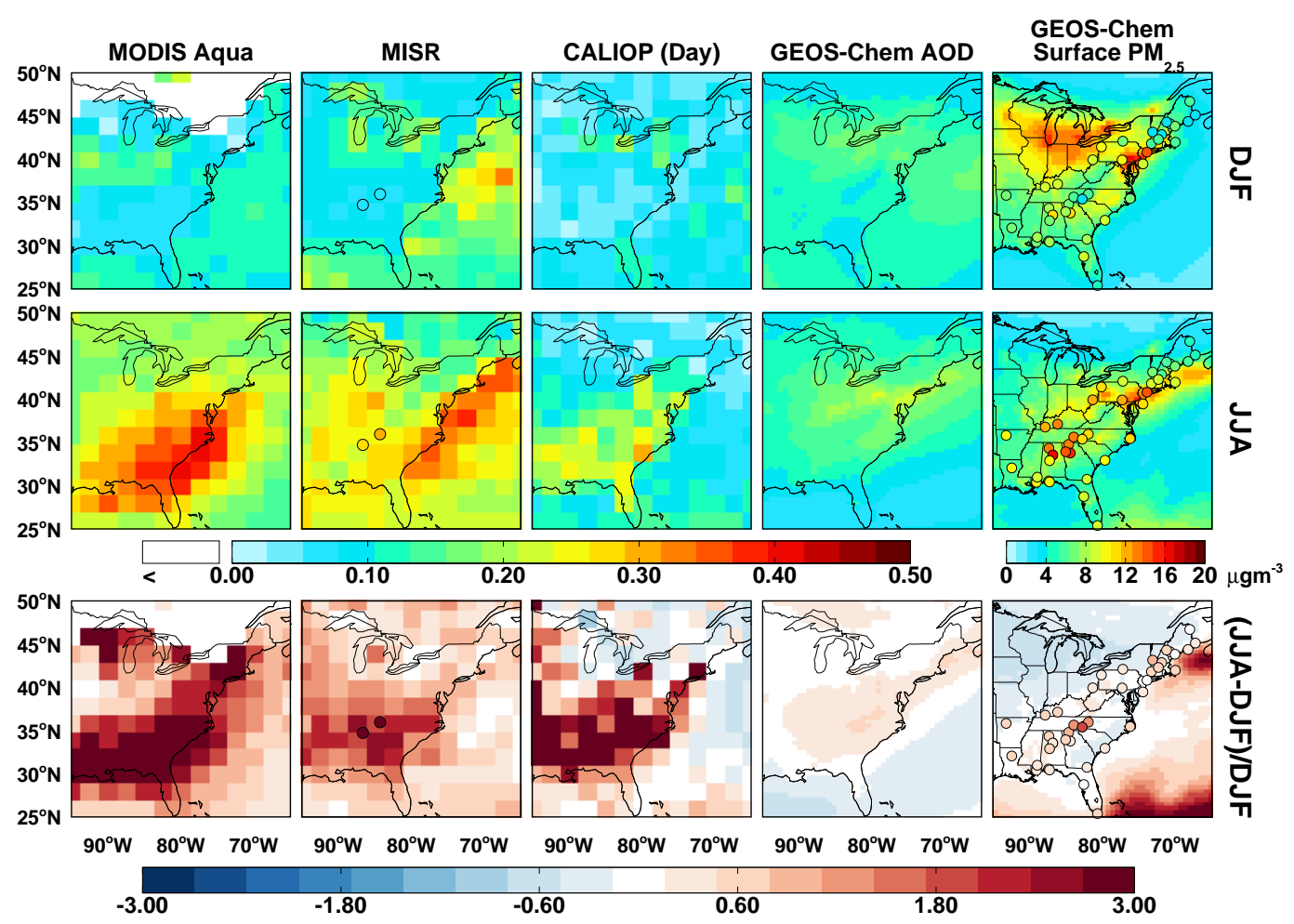

Fig. 1. Seasonally averaged total column AOD for winter (DJF, top row) and summer (JJA, middle row) for December 2006-August 2009 as observed by MODIS (column 1), MISR (column 2), and CALIOP (daytime, column 3) gridded to $2^{\circ} \times 2.5^{\circ}$ and compared to simulated AOD from GEOS-Chem (column 4). Concentrations of surface $\mathrm{PM}_{2.5}$ simulated by GEOS-Chem are overlaid with concentrations measured at IMPROVE and SEARCH network sites (circles) in column 5. Bottom row shows the relative enhancement of summer over winter for observed and simulated AOD and surface concentrations. Average AOD observed at the University of Alabama, Huntsville, and Walker Branch AERONET sites for 2008-2009 is overlaid (circles) on the MISR maps.

from a tapered element oscillating microbalance (TEOM) to characterize the diurnal variability.

All eight of the SEARCH sites and several IMPROVE sites are co-located with nephelometers, which provide measurements of ambient relative humidity (RH). For comparisons of vertical profiles of $\mathrm{RH}$, we also use ground based soundings from 8 National Oceanic and Atmospheric Administration (NOAA) sites (http://weather.uwyo. edu/upperair/sounding.html). Locations of these IMPROVE, SEARCH, and NOAA sounding sites are shown in Figs. 1 and 4.

\subsection{GEOS-Chem}

We use v9.01.01 of the GEOS-Chem chemical transport model, driven by GEOS-5 meteorology, in the nested grid configuration over North America $\left(0.5^{\circ} \times 0.667^{\circ}\right.$ horizontal resolution). The GEOS-Chem aerosol simulation includes sulfate, nitrate, ammonium (Park et al., 2004), primary carbonaceous aerosols (Park et al., 2003), dust (Fairlie et al., 2007; Ridley et al., 2012), sea salt (Alexander et al., 2005), and secondary organic aerosols (SOA) (Henze et al., 2008). Aerosols and gases are removed by both wet and dry deposi- tion in the model. The wet deposition scheme includes scavenging in convective updrafts, rainout and washout (Liu et al., 2001), while dry deposition of gases and aerosols is dependent on surface characteristics and meteorological conditions (Wesely, 1989; Wang et al., 1998). The EPA NEI99 inventory (scaled to be year-specific) is used for most anthropogenic and biofuel emissions over the USA (Hudman et al., 2007, 2008); however, anthropogenic emissions of black and organic carbon follow Cooke et al. (1999) with the seasonality from Park et al. (2003). Biogenic VOC emissions are calculated interactively using the Model of Emissions of Gases and Aerosols from Nature (MEGAN) (Guenther et al., 2006), while year-specific biomass burning is specified according to the Global Fire Emissions Database (GFED2) inventory (van der Werf et al., 2006). We implement a fix for artificially low nighttime boundary layer heights in the GEOS-5 product as well as a $25 \%$ reduction in the $\mathrm{HNO}_{3}$ concentrations, both of which improve comparisons with surface nitrate observations in the United States as described by Heald et al. (2012).

We calculate surface $\mathrm{PM}_{2.5}$ in the model by combining sulfate, nitrate, ammonium, elemental carbon, organic matter (organic carbon scaled by a factor of 1.8 to account for total organic matter, consistent with IMPROVE and SEARCH 
Table 1. Mass extinction efficiency values used in GEOS-Chem for sulfate aerosols at given relative humidity values.

\begin{tabular}{cc}
\hline $\begin{array}{c}\text { Relative Humidity } \\
(\%)\end{array}$ & $\begin{array}{c}\text { Mass Extinction Efficiency } \\
\left(\mathrm{m}^{2} \mathrm{~g}^{-1}\right)\end{array}$ \\
\hline 0 & 2.24 \\
50 & 6.12 \\
70 & 8.90 \\
80 & 11.90 \\
90 & 19.09 \\
95 & 32.75 \\
99 & 104 \\
\hline
\end{tabular}

measurements), fine dust, and accumulation mode sea salt concentrations in the lowest grid box. For comparison with IMPROVE and SEARCH daily $\mathrm{PM}_{2.5}$ measurements, we compute $24 \mathrm{~h}$ averages and sample the data to site locations and measurement days.

Aerosol optical depth in the model is calculated for a specific wavelength using the extinction efficiency $\left(Q_{\text {ext }}\right)$, the column mass loading $(M)$, effective radius $\left(r_{\text {eff }}\right)$, and particle mass density $(\rho)$ such that the AOD $(\tau)$ is calculated by the following equation (Tegen and Lacis, 1996):

$\tau=\frac{3 Q_{\mathrm{ext}} M}{4 r_{\mathrm{eff}} \rho}=\alpha M$

The aerosol mass extinction efficiency $(\alpha)$ is calculated with Mie code based on wavelength-resolved optical and size parameters at 7 relative humidity values $(0,50,70,80,90,95$ and $99 \%$ ) for various aerosol types from the Global Aerosol Data Set (GADS) (Koepke et al., 1997), with recent updates based on Drury et al. (2010), Jaeglé et al. (2010), and Ridley et al. (2012). The extinction efficiency for each grid box is calculated from local relative humidity conditions (Martin et al., 2003). In order to determine whether the observed seasonality in AOD can be attributed to changes in mass loading or mass extinction efficiency, we explore the sensitivity of the mass extinction efficiency to the observed seasonal changes in relative humidity (Sect. 3.2). For this purpose, we use the properties of sulfate aerosol (Table 1), which exhibits the strongest relationship with relative humidity (i.e., the largest hygroscopicity).

\section{Results}

\subsection{Seasonality in AOD and surface concentrations}

We mimic the seasonal AOD comparisons of Goldstein et al. (2009) in Fig. 1 for 2007-2009 using observations from MODIS Aqua, MISR, and CALIOP. Figure 1 also shows the seasonal mean AOD measured by ground-based sun photometers at two AERONET sites in the SEUS.

Figure 1 shows that observed summertime AOD is consistently higher than wintertime values in the SEUS by a

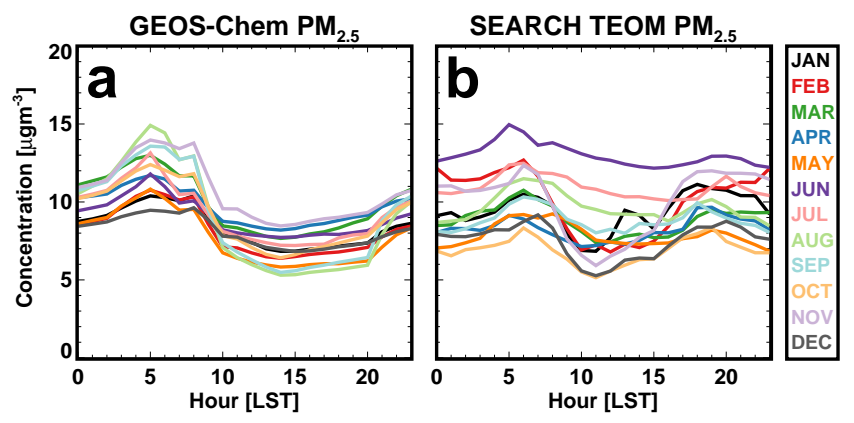

Fig. 2. Diurnal cycles of monthly mean $\mathrm{PM}_{2.5}$ concentrations as simulated by GEOS-Chem (a) and as measured by TEOM filters at SEARCH network sites (b), color-coded by month in 2009 over which the averaging was done.

factor of 2-3. This is consistent with Alston et al. (2012), who find a threefold increase in summertime AOD over wintertime, although they use a finer resolution product and therefore show greater spatial variability. The magnitude of both the seasonal mean and the relative enhancement differs among instruments as shown in the figure, but is spatially consistent. Similar summertime enhancements are reported at AERONET sites in 2008-2009. Furthermore, AOD measurements at the two AERONET sites show little variability during daylight hours $(<20 \%$ in summertime) and suggest that this enhancement is consistent throughout the day. Four independent observations, made with four different measurement techniques, all indicate a large regional enhancement in summertime AOD.

We contrast these observations with the GEOS-Chem chemical transport model simulation. Simulated summertime enhancements in AOD through the Eastern US range from $15-40 \%$. While the model does show a summertime maximum in AOD over the Ohio River Valley and Northeastern US associated with increases in sulfate via $\mathrm{SO}_{2}$ oxidation (Chin et al., 2000) and stagnation events, it does not reproduce the strong observed seasonality in column AOD over the SEUS.

The fourth column of Fig. 1 shows the GEOS-Chem simulated surface concentrations of $\mathrm{PM}_{2.5}$ overlaid with observations from the SEARCH and IMPROVE networks. Comparison with surface observations indicates that GEOSChem generally captures the spatial, seasonal, and diurnal (Fig. 2) variation of $\mathrm{PM}_{2.5}$ in the Eastern US, as will be discussed in further sections and consistent with previous studies (e.g., Heald et al., 2012; Leibensperger et al., 2012). However, Fig. 1 shows that the measured surface concentrations exhibit only a fraction of the seasonality in the column AOD observed by the satellite instruments, suggesting that changes in surface concentrations do not dictate the seasonality observed in AOD. This is in agreement with Alston et al. (2012), who show that the summertime enhancement in surface $\mathrm{PM}_{2.5}$ in Georgia is considerably less than the 


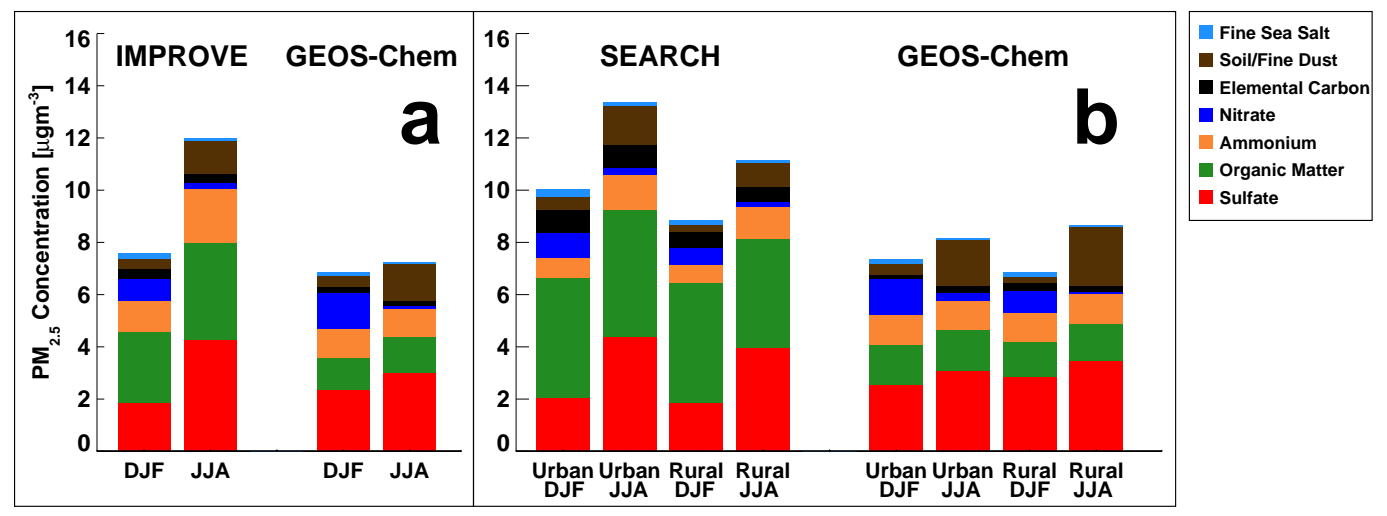

Fig. 3. Mean seasonally averaged surface mass concentrations of $\mathrm{PM}_{2.5}$ (a) observed at the 13 IMPROVE network sites in the SEUS and as simulated by GEOS-Chem (sampled to the IMPROVE sampling days and corresponding model grid boxes). (b) Same as (a) for SEARCH network sites. All data are for December 2006-2009, except for SEARCH sea salt, which only uses data from 2009.

AOD enhancement over the region. This presents an intriguing disconnect between surface and column measurements of aerosol loading in the SEUS.

In Fig. 3, we explore the chemical composition of surface $\mathrm{PM}_{2.5}$ over the SEUS in winter and in summer. Overall, the model captures the chemical speciation and the seasonality of IMPROVE surface concentrations in the region (Fig. 3a), but somewhat underestimates the observed summertime enhancement (mean $\mathrm{PM}_{2.5}$ concentration is $\sim 55 \%$ greater in the summertime). The observed surface seasonality is mainly due to inorganic species. Both observed and simulated nitrate concentrations are higher in the wintertime, consistent with more favorable formation of ammonium nitrate at cooler temperatures, while the increase in observed summertime sulfate is the result of enhanced $\mathrm{SO}_{2}$ oxidation (Chin et al., 2000). The model simulation underestimates the doubling in sulfate concentrations from winter to summer seen at IMPROVE sites (specifically the Appalachian sites), but does capture the summertime enhancement associated with dust transport from North Africa (Ridley et al., 2012).

Observed OM at IMPROVE sites in the SEUS is consistently $\sim 2-4 \mu \mathrm{gm}^{-3}$, making up less than $35 \%$ of mean observed $\mathrm{PM}_{2.5}$, consistent with the analysis of Hand et al. (2012). Zhang et al. (2012a) find slightly higher $\mathrm{OM} / \mathrm{PM}_{2.5}$ fractions (40-50\%) in urban areas in the SEUS; however, when biomass burning events are removed, the fraction of water-soluble $\mathrm{OM} / \mathrm{PM}_{2.5}$ that they observe is reduced to $\sim 25 \%$. GEOS-Chem underpredicts OM concentrations by about a factor of two, consistent with other regions of the world (Heald et al., 2011). However, the magnitude of OM seasonality is similar between the observations and model with very little variation in OM throughout the year (a 35\% increase in summer over winter), in agreement with values reported by Zhang et al. (2012a). The seasonality in $\mathrm{OM}$ (and consequently $\mathrm{PM}_{2.5}$ ) might be enhanced if we used a varying $\mathrm{OM} / \mathrm{OC}$ ratio, as studies have shown that the ratio is greater in the summer than in the winter (e.g., Simon et al., 2011). However, the ratio would be applied to both the model simulation and observations, and, as GEOS-Chem is already able to simulate the OM seasonality, would therefore not explain the model discrepancy. We also compare these OM concentrations and seasonality with IMPROVE sites in the Northeastern US, where there is less of an increase in summertime AOD, and find similar values at the surface.

Observations from the SEARCH network show less seasonal variability in $\mathrm{PM}_{2.5}$ than the IMPROVE sites, as shown in Fig. 3b, which also highlights the differences between rural and urban sites. As expected, $\mathrm{PM}_{2.5}$ concentrations are greater at urban sites and in particular sulfate and elemental carbon concentrations are higher. Additionally, although GEOS-Chem is able to simulate dust concentrations and seasonality at IMPROVE sites, it slightly overpredicts summertime dust at SEARCH sites, especially rural sites. There are also higher concentrations and more seasonality in the OM at urban sites, consistent with Yan et al. (2009). Overall, the OM fraction at these SEARCH sites is greater than observed at the IMPROVE sites (Fig. 3a). Thus the model underestimate of $\mathrm{OM}$ is also greater. However, even more so than the IMPROVE comparisons, both the SEARCH observations and the simulation of concentrations at these sites show very little seasonal variation in $\mathrm{OM}$ at both rural and urban sites. Additionally, there is little diurnal variability in $\mathrm{PM}_{2.5}$ (Fig. 2, relative standard deviation of $\sim 10 \%$ throughout the year), which confirms that the seasonality in surface concentrations is consistent throughout the day and that using a $24 \mathrm{~h}$ average $\mathrm{PM}_{2.5}$ concentration rather than a $1 \mathrm{~h}$ average $\mathrm{PM}_{2.5}$ concentration sampled to the satellite overpass times does not bias the comparison with satellite observations provided at two snapshots.

We conclude that the seasonality in satellite AOD over the SEUS does not match the surface concentrations or more specifically organic aerosol at the surface. This weaker 

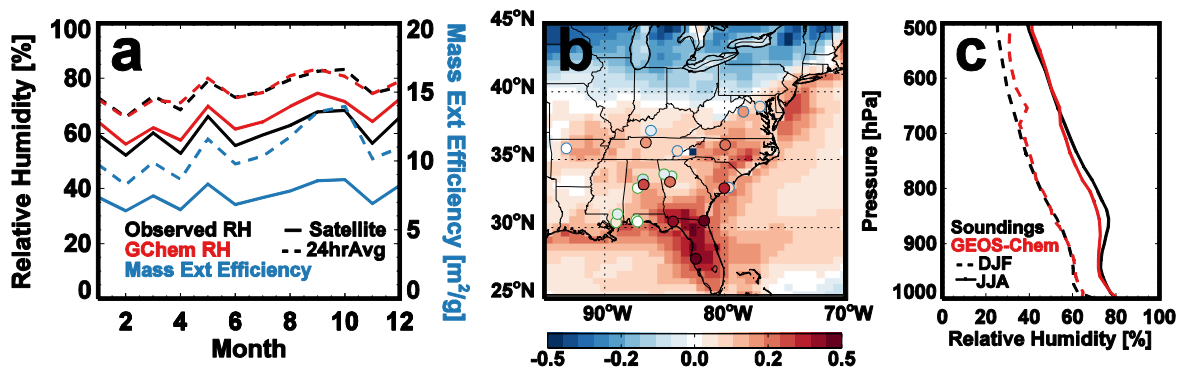

Fig. 4. (a) Average 2009 monthly surface RH recorded at IMPROVE and SEARCH network nephelometer sites (black) using $24 \mathrm{~h}$ averages (dashed line) and sampled to the afternoon overpass time (solid line). These are compared with values used in GEOS-Chem (red lines) sampled to observational site locations and converted to mass extinction efficiency values (for sulfate aerosols, blue lines). (b) Fractional increase in surface mass extinction efficiency of summer over winter simulated with GEOS-Chem and overlaid with values calculated from surface RH observed at IMPROVE nephelometer (blue circles), SEARCH (green circles) and sounding (black circles) sites for 2009. GEOSChem, SEARCH and IMPROVE data are sampled for the afternoon satellite overpass time (13:00-15:00 LT) and the sounding data are averages from 00:00 and 12:00 UTC. (c) Mean profile of RH measured at the 8 sounding sites (black lines) at 00:00 and 12:00 UTC and the corresponding RH in GEOS-Chem (red line) sampled to the site locations and times for winter (dashed) and summer (solid) 2009.

correlation between column AOD and $\mathrm{PM}_{2.5}(R=0.2-0.31$ for daily matched pairs across the region) in the SEUS contrasts other regions where previous studies have found a strong correlation between satellite-observed column AOD and surface concentrations throughout the year $(R=0.39$ 0.9, e.g., Engel-Cox et al., 2004; Al-Saadi et al., 2005; van Donkelaar et al., 2006; Paciorek and Liu, 2009; Zhang et al., 2009; van Donkelaar et al., 2010). These previous studies note that discrepancies often arise in comparing surface concentrations and column AOD due to inaccurate assumptions or lack of information about the hygroscopicity of the aerosols, the composition, size distributions, the vertical distribution of aerosols, the presence of transported aerosols above the surface layer, and the meteorological environment, especially with regards to clouds. Correlations are highest when the aerosol is near the surface, uniformly mixed, relative humidity is moderate, and coarse mode aerosol fraction is small (Al-Saadi et al., 2005; van Donkelaar et al., 2006). Therefore, in the following sections we investigate several of these factors in an attempt to determine what, other than surface concentrations, could be driving the seasonality in AOD.

\subsection{Effect of relative humidity}

Changes in aerosol water uptake could play a role in the seasonality of AOD in the SEUS. This is briefly examined by Goldstein et al. (2009), who find that the AOD and relative humidity (RH) at a single AERONET site (Walker Branch) are only weakly correlated across seasons. We investigate this further at several locations to better represent the effect of $\mathrm{RH}$ on a broader region of the SEUS. In addition, given that water uptake is already included in the simulation of AOD, we explore whether there is any evidence of a bias in RH in the GEOS-5 meteorology, which could degrade the model simulation of AOD.
Hourly surface RH values used in GEOS-Chem are highly correlated with observations from the IMPROVE and SEARCH network nephelometer sites $(R=0.6-0.83$ across sites and seasons), with a mean bias of less than $5 \%$. Correlations are highest during the morning and afternoon hours and degrade during the nighttime and at coastal sites (where GEOS-Chem has a low RH bias). Figure 4a demonstrates that there is little seasonality in mean surface $\mathrm{RH}$ in the SEUS, and that the model reproduces both the magnitude and consistency of RH year-round. Monthly RH values averaged over all the sites vary less than $10 \%$ throughout the year at the 13:30 satellite overpass and less than $20 \%$ when all hours are used to construct monthly means.

In order to examine the impact of these modest seasonal differences in RH on AOD, we use the optical properties applied to aerosols in GEOS-Chem to convert these differences in $\mathrm{RH}$ to differences in aerosol mass extinction efficiency. For simplicity, we use sulfate aerosol properties, which have the highest hygroscopicity (other than $\mathrm{NaCl}$, which is not a significant contributor to aerosol mass in the region) (Petters and Kreidenweis, 2007) and would be the most affected by changes in RH. At the surface, seasonal differences in mass extinction efficiency due to water uptake account for less than a $25 \%$ increase in aerosol extinction from winter to summer over the SEUS (Fig. 4b).

The seasonality in the vertical profile of $\mathrm{RH}$ measured at the 8 NOAA sounding sites in the region is larger, with about a $20 \%$ absolute increase in mean RH from winter to summer throughout the troposphere (Fig. 4c). However, the seasonal difference in aerosol extinction resulting from water uptake ( $40 \%$ when integrated over the column assuming sulfate aerosol) can account for only a fraction of the 100$300 \%$ difference in AOD observed by the satellite instruments over the SEUS (Fig. 1). While this increase in summertime RH is generally captured by the model (and thus reflected in the simulated AOD seasonality), RH values in the 

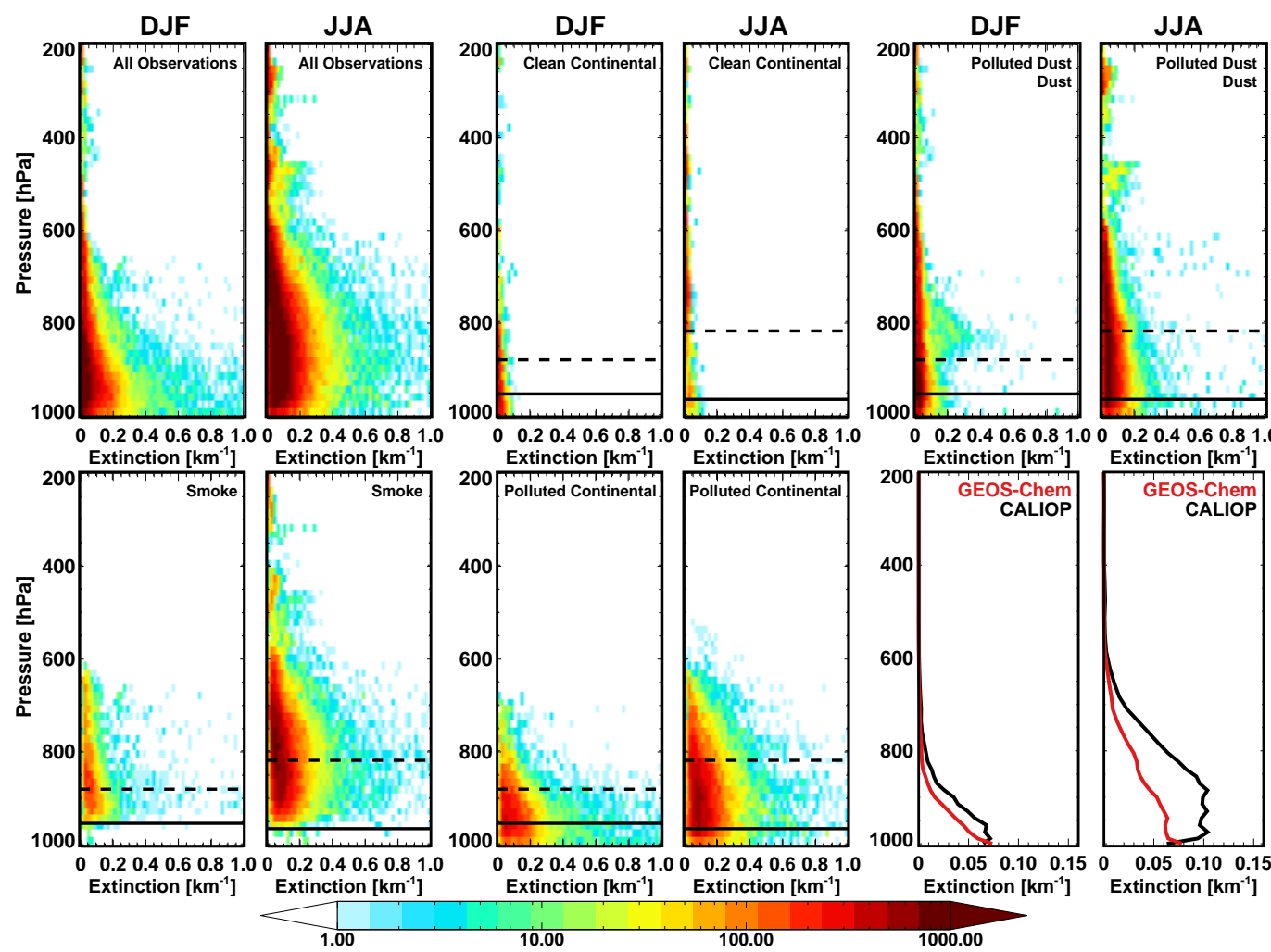

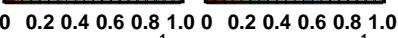
Extinction $\left[\mathrm{km}^{-1}\right] \quad$ Extinction $\left[\mathrm{km}^{-1}\right]$ Extinction $\left[\mathrm{km}^{-1}\right]$ Extinction $\left[\mathrm{km}^{-1}\right]$
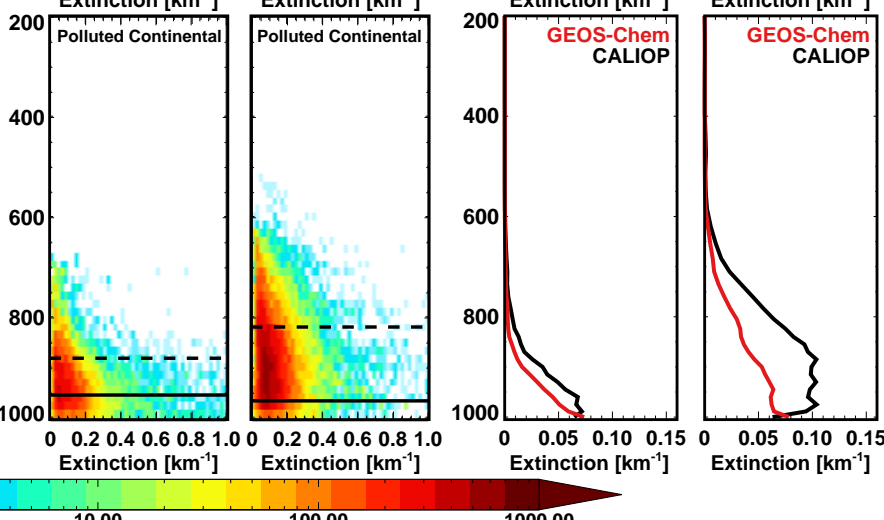

Fig. 5. Density plots of all nighttime aerosol extinction values observed by CALIOP for winter and summer seasons of 2007-2009 over the SEUS (30.5-37.5 $\mathrm{N}$ and $\left.90-81.5^{\circ} \mathrm{W}\right)$, classified by aerosol type. The color denotes the number of observations with given extinction values at a given altitude. There are $\sim 70000$ extinction values for the winter and $\sim 200000$ for the summer from December 2006-2009, including values below the detection limit. Panels 1 and 2 show observations with all aerosol types noted, and panels 3-10 separate values based on aerosol type, with seasonally averaged boundary layer heights from GEOS-Chem for nighttime (solid black horizontal lines) and daytime (dashed lines) overlaid. Bottom right panels show average aerosol extinction profiles as observed by CALIOP (black) and the corresponding profiles simulated by GEOS-Chem and sampled to the CALIOP overpasses (red) for the two seasons applying detection limits as in Ford and Heald (2012).

lower troposphere $(900-700 \mathrm{hPa})$ are slightly underestimated in summertime $(<5 \%)$. This translates to a $5-12 \%$ underestimate in sulfate extinction efficiency in GEOS-Chem at these altitudes; however, the effect is likely to be more modest for the mix of ambient aerosol with lower hygroscopicity. Therefore, aerosol water uptake cannot explain the observed seasonality in AOD, nor can biases in RH explain the model underestimate of this seasonality.

Although we only show the sensitivity of the mass extinction efficiency to RH here, we also note that changes to the aerosol size distribution not accounted for in the model could impact the observed AOD. Heald et al. (2010) use Mie code to estimate that uncertainty in mass extinction efficiency associated with the size of OM (associated with a doubling or halving of the assumed mean geometric radius and varying the geometric standard deviation from values of 1.4 to 1.8 ) is $\sim 50 \%$. Therefore, a seasonal shift towards larger particles in summertime could account for some of the model-measurement discrepancy. However, measurements of the geometric mean diameters for ambient SOA- dominated aerosol and fresh smoke are similar (Levin et al., 2009, 2010). Additionally, the fraction of total AOD accounted for by organics in the model is on average less than $15 \%$ in the summertime, and substantial seasonal changes in the size of inorganic aerosol are less likely (e.g., Stanier et al., 2004; Zhang et al., 2008), so it is unlikely that shifts in the fine aerosol size distribution are a dominant source of model error.

\subsection{The vertical profile of aerosol}

The lack of strong seasonality in surface aerosol concentrations and aerosol water content throughout the vertical column suggests that summertime increases in AOD over the SEUS must be associated with an increase in aerosol mass above the surface layer that is not accounted for in GEOS-Chem, potentially consistent with the hypothesis of Goldstein et al. (2009), which suggests a missing source of aerosols aloft. 
Winter and summer vertical distributions of all the nighttime aerosol extinction values reported by CALIOP for three years (2007-2009) over the SEUS are shown in Fig. 5. Separating profiles based on aerosol type indicates broadly what sources are likely to contribute to the mass loading in each season, although the CALIOP algorithm is based on physical properties and does not distinguish aerosol by chemical composition.

Figure 5 shows that there are larger aerosol extinction observations at higher altitudes during the summer months. There is little seasonal difference in GEOS-5 nighttime boundary layer height (coincident with CALIOP measurements), but the deeper daytime mixed layers in summer may vertically distribute aerosol to higher altitudes. We investigate the impact of the mixing heights on the vertical profile in the next section.

In the final panels of Fig. 5, we compare the average nighttime profiles of aerosol extinction observed over the region by CALIOP with the average profile simulated by GEOS-Chem. First, these profiles confirm that the mean observed extinction profile over the SEUS is higher in the summer than in winter. The integrated mean AOD from these profiles increases more than threefold from winter to summer $(0.07$ to 0.25$)$, consistent with the picture presented in Fig. 1. Second, these profiles demonstrate that the model underestimate of summertime AOD shown in Fig. 1 is associated with above-surface aerosols. The simulated and observed profile shapes are similar in the wintertime, but the model greatly underpredicts aerosol extinction above the surface layer in summer. While there might be a bias in the CALIOP measurements near the surface due to interference of clouds, lower sensitivity, and/or inclusion of clear air retrievals below aerosol layers (Winker et al., 2013), surface extinction values are generally reproduced by the model throughout the year, consistent with our $\mathrm{PM}_{2.5}$ surface comparisons in Figs. 1 and 3. Additionally, the retrieval sensitivity of CALIOP increases with altitude (Winker et al., 2009), and Sheridan et al. (2012) suggest that if there is a bias in the free troposphere, it is a low bias (particularly under cloud-free conditions, as shown here), which suggests that the discrepancy in extinction above the surface layer between the simulated and measured profile is unlikely to be due to systematic observational errors.

Mean summertime AOD calculated by integrating the model profile in Fig. 5 is 0.12 , less than half the mean CALIOP values. While these profiles do not suggest that there is a distinct lofted layer of aerosol, they do indicate that the seasonality in AOD is primarily associated with an increase in aerosol mass above the surface layer in the lower troposphere (below $700 \mathrm{hPa}$ ), which is not captured by the GEOS-Chem model. This discrepancy is inconsistent with Heald et al. (2011), who show that the GEOS-Chem model generally captures the profiles of sulfate and organic aerosol in the Northern Hemisphere, even when concentrations are significantly underestimated.
We distinguish these CALIOP profiles by the observed aerosol types to understand the source of these aerosols, and Fig. 5 shows that the majority of aerosols observed in the SEUS is classified as polluted dust, polluted continental, and smoke. The maximum in dust above the boundary layer in the winter is likely due to dust transport from the Western US, while increases in the summer are associated with transport of African dust.

The summertime enhancement of extinction above the surface layer is predominantly associated with smoke and polluted continental aerosol types. This could indicate that aerosols from biomass burning are the cause of the seasonal difference. While previous studies have shown that biomass burning in the SEUS generally peaks in late winter and early spring (Zeng et al., 2008; Tian et al., 2009; Zhang et al., 2010), MODIS fire counts in this region almost double from winter to summer in 2007-2009. Furthermore, the GFED2 biomass burning emissions used in the model prescribe a factor of 3-4 increase from winter to summer for these years. However, this is largely offset by a decrease in emissions of carbonaceous aerosols from anthropogenic sources in summertime, such that increases in total emissions of carbonaceous aerosols are modest (20-30\%). This is consistent with the seasonal changes reported in simulated surface carbonaceous $\mathrm{PM}_{2.5}$ (Fig. 3). The contribution of OM to seasonally averaged total AOD is less than $15 \%$ in both summer and winter, suggesting that potential seasonal differences in $\mathrm{OM}$ injection heights would have little impact on the total extinction profile. Near the surface, smoke aerosols appear to have little impact; however, this is likely due to the CALIOP algorithm, which generally requires that aerosols be in an elevated layer in order to be classified as smoke (Omar et al., 2009) and will otherwise be classified as polluted continental. Thus, aerosol identified by CALIOP as either polluted continental or smoke may be of the same chemical composition and origin and may not be directly linked to fire activity. However, because the same $532 \mathrm{~nm}$ lidar ratio is used for smoke and polluted continental aerosols, a misclassification will not bias the extinction profile.

\subsection{Effect of planetary boundary layer height}

One possible explanation of a large seasonal enhancement in AOD with modest change to surface $\mathrm{PM}_{2.5}$ is a summertime aerosol source with a coincident deepening of the mixed layer. As shown in Fig. 5, this deepening of the daytime planetary boundary layer (PBL) is simulated in the GEOS-Chem model, with an increase of more than $60 \mathrm{hPa}$ from winter to summer on average. The CALIOP average summer profile suggests that the higher concentrations above the surface are relatively uniform over a deep layer (up to $800 \mathrm{hPa}$ ), which could indicate that the GEOS-Chem simulation does not mix pollutants through a deep-enough layer of the atmosphere, although we note that this altitude is similar to the mean summertime PBL depths used in the model (shown in Fig. 5). If 
the PBL heights used in the model are too shallow, pollutants could be trapped and more easily removed before being mixed upward.

The diurnal cycle of surface concentrations can provide some information about vertical mixing. For relatively constant emissions, surface concentrations generally increase at night with a shallow boundary layer and then, as the PBL height grows throughout the day, pollutants are diluted and surface concentrations decline. Thus, a shallow bias in summertime afternoon mixed layer would reduce the diurnal variability in simulated $\mathrm{PM}_{2.5}$ concentrations. However, the diurnal cycles of simulated and observed $\mathrm{PM}_{2.5}$ at SEARCH sites are relatively similar (Fig. 2), with observations showing slightly more consistency throughout the day, especially in the summer months. The observations shown here are consistent with Weber et al. (2003), who show that on average $\mathrm{PM}_{2.5}$ concentrations in Atlanta during August generally vary less than $20 \%$ through the day due to sulfate peaking in the afternoon while OM, elemental carbon, and nitrate and nitrate tend to peak in the early morning. Thus, while the contribution of the timing of different sources and mixing depths to the diurnal profile can be a challenge to untangle, the ability of the model to capture a relatively flat profile in surface $\mathrm{PM}_{2.5}$, as well as the overall seasonality and composition of that $\mathrm{PM}_{2.5}$ (Fig. 3), provides evidence of a relatively unbiased simulation of mixing depth.

It remains a challenge to validate the PBL heights used in the model simulation as there are several different approaches used to estimate the height of the PBL, all of which can produce differing results (e.g., Berman et al., 1997). As shown in Marsik et al. (1995), various measurement systems can at some times differ on the height of the PBL over Atlanta by almost $1 \mathrm{~km}$. Therefore, we examine the sensitivity of the vertical profile and summertime AOD to changes in mixing depth in model simulations. We perform four simulations for summer 2009, in which (1) PBL heights are raised by $100 \mathrm{hPa}$ at all hours of the day, (2) PBL heights are raised by $100 \mathrm{hPa}$ only during daytime hours of $7.00 \mathrm{a} . \mathrm{m}$. to $7.00 \mathrm{p} . \mathrm{m}$. LT, (3) $\mathrm{SO}_{2}$ emissions in North America are doubled, and (4) $\mathrm{SO}_{2}$ emissions are doubled and the daytime PBL heights are raised. The impact of these simulations on the average regional profile is shown in Fig. 6.

Raising the PBL for all hours of the day increases extinction values throughout most of the profile, particularly at the top of the PBL, as concentrations are mixed throughout a deeper layer. However, values near the surface decrease as aerosols are mixed away from the surface into the deeper PBL, particularly at night. In the simulation where the PBL is only raised during the day, aerosol extinction values near the surface are similar to the original profile, but greater above the nighttime PBL, in the daytime residual layer. However, both of these simulations continue to substantially underpredict the extinction values compared to CALIOP (AOD increases by only 0.02 over the region), suggesting that a po-

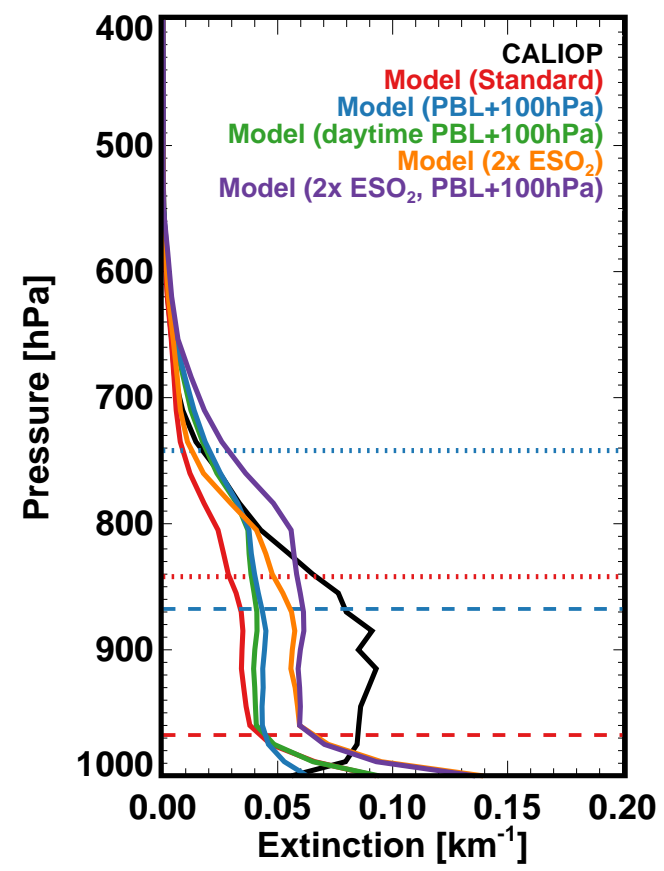

Fig. 6. Aerosol extinction profiles over the SEUS for JJA 2009 as observed by CALIOP (black) and as simulated by GEOS-Chem with original PBL heights (red), PBL heights raised by $100 \mathrm{hPa}$ at all hours (blue), raised by $100 \mathrm{hPa}$ during daytime hours (green), doubled $\mathrm{SO}_{2}$ emissions (orange), and doubled $\mathrm{SO}_{2}$ emissions and PBL heights raised during daytime hours (purple). Average PBL heights are shown in red for original simulation and blue for simulations with raised PBL heights, with dashed lines for nighttime and dotted lines for daytime.

tential bias in the PBL height would not be enough to explain the discrepancy in AOD.

Finally, we verify whether the aerosol profile measured by CALIOP is consistent with an increase in existing sources. We test increasing the sources of sulfate, which would be consistent with both the surface underestimate shown in Fig. 3 as well as the possibility of formation aloft via incloud processing. The profiles in Fig. 6 demonstrate that doubling $\mathrm{SO}_{2}$ emissions effectively scales up the entire simulated profile, but in doing so significantly degrades the comparison with both CALIOP and the speciated surface concentrations (not shown). Simultaneously increasing the daytime PBL heights produces virtually the same profile, but produces an overestimate of observed aerosol extinction from $800-700 \mathrm{hPa}$. We therefore conclude that an increase in mixing depth, with or without a coincident increase in an existing aerosol source, cannot explain the observed CALIOP profile. This implies that the underestimate in aerosol mass aloft is due to an additional above-surface source. Using the average summertime mass extinction efficiency and the difference between the satellite-estimated and simulated extinction profile, we roughly estimate that this additional source is 


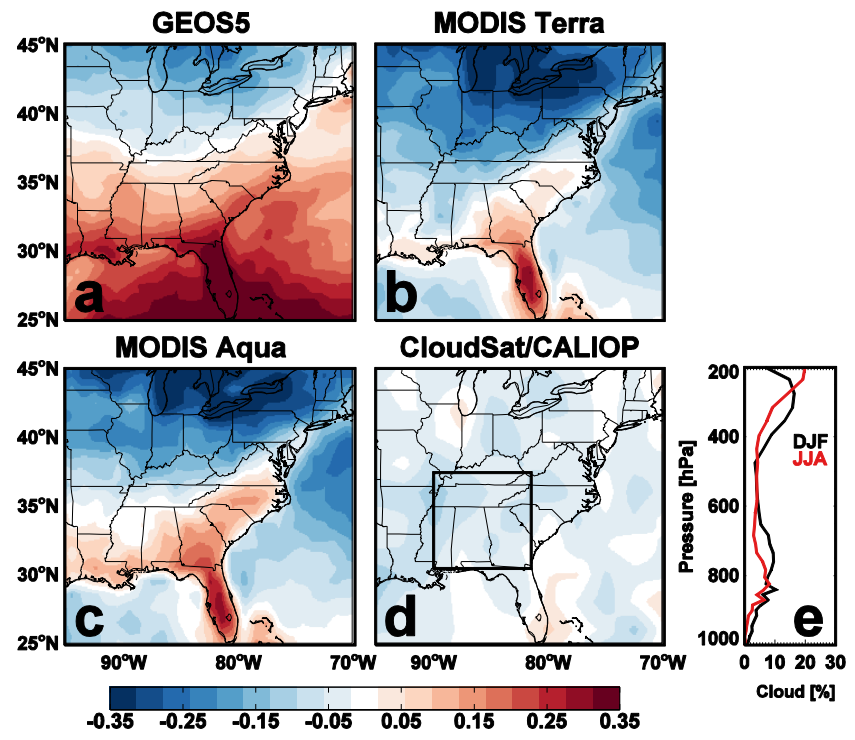

Fig. 7. Differences (summer-winter) between average cloud fraction for 2006-2009 (a) from GEOS-5 sampled to afternoon overpass, (b) observed by MODIS onboard Terra and (c) Aqua, and (d) observed by CloudSat/CALIOP. Black outline shows region for profiles of average cloud fraction over the SEUS for winter (black) and summer (red) observed by CloudSat/CALIOP in 2009 shown in panel (e).

equivalent to three times the current sulfate mass (above the surface only).

\section{Discussion}

Satellite observations show a strong summertime enhancement in AOD over the SEUS, previously linked with biogenic activity, which is not observed in surface $\mathrm{PM}_{2.5}$ concentrations. By determining here that there is little agreement between surface concentrations and column AOD in the Southeastern US, we surmise that changes in surface mass concentrations do not control the seasonality of AOD in the region. Furthermore, the GEOS-Chem model generally captures observed surface concentrations (with the exception of a modest underestimate of summertime sulfate and year-round underestimate of OA), but it does not reproduce the observed AOD seasonality, indicating an underestimation of aerosol extinction above the surface layer in the model. We show that neither a bias in model RH (and hence aerosol water uptake) nor summertime mixing depths can explain this discrepancy. Zhang et al. (2012b) show that GEOS-Chem reproduces wet deposition measurements in the US. This suggests that this discrepancy is also not due to a bias in aerosol removal but rather a missing source of aerosol above the surface layer.

CALIOP measurements provide additional evidence of aerosol production above the surface; however, our interpretation is limited by the lack of aerosol chemical specia- tion. Ervens et al. (2011) suggest that in regions where there are large biogenic VOC and anthropogenic emissions, high $\mathrm{RH}$, and cloudiness, yields from aqueous formation of SOA can be significant. Carlton et al. (2008) show that including SOA formation through cloud processing modestly improves model simulations of airborne OA observations in the Northeastern US. Sooroshian et al. (2007) also observe elevated organic aerosol layers above clouds during field campaigns over Texas and California due to the formation of organic acids from aqueous phase reactions, which subsequently undergo droplet evaporation. Cloudy conditions as well as enhanced oxidant concentrations in summertime could also augment sulfate production, which we show is moderately underestimated at the surface in summertime in our simulation. It has also been suggested that including reactions of stabilized Criegee intermediates with sulfur dioxide in models can produce a $10-25 \%$ increase in sulfuric acid $\left(\mathrm{H}_{2} \mathrm{SO}_{4}\right)$ annually and a $100 \%$ increase in July (Pierce et al., 2013).

GEOS-5 meteorology does show higher cloud fractions over the SEUS in the summer compared to the winter, which is corroborated by observations from MODIS Aqua and Terra (Fig. 7). If clouds are indeed serving as a medium for chemical production, this could explain the increased aerosol loading above the surface layer that is seen in the cloud-free CALIOP profiles shown here. However, observations from the CloudSat Cloud Profiling Radar suggest that mid- to low troposphere cloud cover is highest in the region in winter (Fig. 7). Furthermore, we see no evidence of a correlation in daily cloud optical depth and aerosol extinction reported by CloudSat and CALIOP over the region. These conflicting characterizations of cloud seasonality and a lack of correspondence between cloud cover and aerosol loading suggest that cloud liquid water may not be the limiting factor in summertime aerosol production, but rather that the oxidation of biogenic VOCs, whose emission peaks in summertime, is required to explain the observed aerosol enhancement above the surface layer.

It is vital, therefore, to have in situ vertical measurements of aerosol composition in order to fully investigate this hypothesis of increased aqueous aerosol production aloft and determine whether it is organic or inorganic in nature. The SAS campaign aircraft data will be critical for resolving this issue and determining the aerosol characteristics in the SEUS, thus enabling a better prediction of how aerosol in this region is likely to evolve.

Acknowledgements. This work was supported by the National Science Foundation (ATM-0929282). We thank the satellite (MODIS, MISR, CALIOP, CloudSat) and in situ measurement teams (AERONET, IMPROVE, SEARCH).

Edited by: P. Stier 


\section{References}

Alexander, B., Park, R. J., Jacob, D. J., Li, Q. B., Yantosca, R. M., Savarino, J., Lee, C. C. W., and Thiemens, M. H.: Sulfate formation in sea-salt aerosols: Constraints from oxygen isotopes, J. Geophys. Res., 110, D10307, doi:10.1029/2004JD005659, 2005.

Al-Saadi, J., Szykman, J., Pierce, R. B., Kittaka, C., Neil, D., Chu, D. A., Remer, L., Gumley, L., Prins, E., Weinstock, L., MacDonald, C., Wayland, R., Dimmick, F., and Fishman, J.: Improving National Air Quality Forecasts with Satellite Aerosol Observations, B. Am. Meteorol. Soc., 86, 1249-1261, 2005.

Alston, E. J., Sokolik, I. N., and Kalashnikova, O. V.: Characterization of atmospheric aerosol in the US Southeast from groundand space-based measurements over the past decade, Atmos. Meas. Tech., 5, 1667-1682, 2012,

http://www.atmos-meas-tech.net/5/1667/2012/.

Berman, S., Ku, J.-Y., Zhang, J., and Rao, S. T.: Uncertainties in estimating the mixing depth-comparing three mixing-depth models with profiler measurements, Atmos. Environ., 31, 3023-3039, 1997.

Carlton, A. G., Turpin, B. J., Altieri, K. E., Seitzinger, S. P., Mathur, R., Roselle, S. J., and Weber, R. J.: CMAQ model performance enhanced when in-cloud secondary organic aerosol is included: comprisons of organic carbon predictions with measurements, Environ. Sci. Technol., 42, 8798-8802, 2008.

Chin, M., Savoie, D. L., Huebert, B. J., Bandy, A. R., Thornton, D. C., Bates, T. S., Quinn, P. K., Saltzman, E. S., and De Bruyn, W. J.: Atmospheric sulfur cycle simulated in the global model GOCART: Comparison with field observations and regional budgets, J. Geophys. Res., 105, 24689-24712, 2000.

Cooke, W. F., Liousse, C., Cachier, H., and Feichter, J.: Construction of a $1^{\circ} \times 1^{\circ}$ fossil fuel emission data set for carbonaceous aerosol and implementation and radiative impact in the ECHAM4 model, J. Geophys. Res., 104, 22137-22,162, 1999.

Diner, D. J., Braswell, B. H., Davies, R., Gobron, N., Hu, J., Jun, Y., Kahn, R. A., Knyazikhin, Y., Loeb, N., Muller, J.-P., Nolin, A. W., Pinty, B., Schaaf, C., Seiz, G., and Stroeve, J.: The value of multiangle measurements for retrievein structurally and radiatively consistent properties of clouds, aerosols, and surfaces, Remote Sens. Environ., 97, 495-518, 2005.

Drury, E., Jacob, D. J., Spurr, R. J. D., Wang, J., Shinozuka, Y., Anderson, B. E., Clarke, A. D., Dibb, J., McNaughton, C., and Weber, R.: Synthesis of satellite (MODIS), aircraft (ICARTT), and surface (IMPROVE, EPA-AQS, AERONET) aerosol observations over eastern North America to improve MODIS aerosol retrievals and constrain surface aerosol concentrations and sources, J. Geophys. Res., 115, D14204, doi:10.1029/2009JD012629, 2010.

Duncan, B. N., Martin, R. V., Staudt, A. C., Yevich, R., and Logan, J. A.: Interannual and seasonal variability of biomass burning emissions constrained by satellite observations, J. Geophys. Res., 108, D2, doi:10.1029/2002JD002378, 4100, 2003.

Edgerton, E. S., Hartsell, B. E., Saylor, R. D., Jansen, J. J., Hansen, D. A., and Hidy, G. M.: The Southeastern Aerosol Research and Characterization Study: Part II. Filter-based measurements of fine and coarse particulate matter mass and composition, J. Air Waste Manag. Assoc., 55, 1527-1542, 2005.

Edgerton, E. S., Hartsell, B. E., Saylor, R. D., Jansen, J. J., Hansen, D. A., and Hidy, G. M.: The Southeastern Aerosol Research and Characterization Study, Part 3: continuous measurements of fine particulate matter mass and composition, J. Air Waste Manag. Assoc., 56, 1325-1341, 2006.

Engel-Cox, J. A., Hoff, R. M., Rogers, R., Dimmick, F., Rush, A. C., Szykman, J. J., Al-Saadi, J., Chu, D. A., and Zell, E. R.: Integrating lidar and satellite optical depth with ambient monitoring for 3-dimensional particulate characterization, Atmos. Environ., 40, 8056-8067, 2006.

Ervens, B., Turpin, B. J., and Weber, R. J.: Secondary organic aerosol formation in cloud droplets and aqueous particles (aqSOA): a review of laboratory, field and model studies, Atmos. Chem. Phys., 11, 11069-11102, doi:10.5194/acp-1111069-2011, 2011.

Fairlie, D. T., Jacob, D. J., and Park, R. J.: The impact of transpacific transport of mineral dust in the United States, Atmos. Environ., 41, 1251-1266, 2007.

Ford, B. and Heald, C. L.: An A-train and model perspective on the vertical distribution of aerosols and $\mathrm{CO}$ in the Northern Hemisphere, J. Geophys. Res., 117, D06211, doi:10.1029/2011JD016977, 2012.

Goldstein, A. H., Koven, C. D., Heald, C. L., and Fung, I. Y.: Biogenic carbon and anthropogenic pollutants combine to form a cooling haze over the southeastern United States, PNAS, 106, 8835-8840, 2009.

Guenther, A., Karl, T., Harley, P., Wiedinmyer, C., Palmer, P. I., and Geron, C.: Estimates of global terrestrial isoprene emissions using MEGAN (Model of Emissions of Gases and Aerosols from Nature), Atmos. Chem. Phys., 6, 3181-3210, doi:10.5194/acp-63181-2006, 2006.

Hallquist, Å. M., Jerksjö, M., Fallgren, H., Westerlund, J., and Sjödin, Å.: Particle and gaseous emissions from individual diesel and CNG buses, Atmos. Chem. Phys., 13, 5337-5350, doi:10.5194/acp-13-5337-2013, 2013.

Hand, J. L., Schichtel, B. A., Pitchford, M., Malm, W. C., and Frank, N. H.: Seasonal composition of remote and urban fine particulate matter in the United States, J. Geophys. Res., 117, D05209, doi:10.1029/2011JD017122, 2012.

Hansen, D. A., Edgerton, E. S., Hartsell, B. E., Jansen, J. J., Kandasamy, N., Hidy, G. M., and Blanchard, C. L.: The Southeastern Aerosol Research and Characterization Study: part 1 - Overview, J. Air Waste Manag. Assoc., 53, 1460-1471, 2003.

Heald, C. L., Wilkinson, M. J., Monson, R. K., Alo, C. A., Wang, G., and Guenther, A.: Response of isoprene emission to ambient $\mathrm{CO} 2$ changes and implications for global budgets, Glob. Change Biol., 15, 1127-1140, 2009.

Heald, C. L., Ridley, D. A., Kreidenweis, S. M., and Drury, E. E.: Satellite observations cap the atmospheric organic aerosol budget, Geophys. Res. Lett., 37, L24808, doi:10.1029/2010GL045095, 2010.

Heald, C. L., Coe, H., Jimenez, J. L., Weber, R. J., Bahreini, R., Middlebrook, A. M., Russell, L. M., Jolleys, M., Fu, T.-M., Allan, J. D., Bower, K. N., Capes, G., Crosier, J., Morgan, W. T., Robinson, N. H., Williams, P. I., Cubison, M. J., DeCarlo, P. F., and Dunlea, E. J.: Exploring the vertical profile of atmospheric organic aerosol: comparing 17 aircraft field campaigns with a global model, Atmos. Chem. Phys., 11, 12673-12696, doi:10.5194/acp-11-12673-2011, 2011.

Heald, C. L., Collett Jr., J. L., Lee, T., Benedict, K.B., Schwandner, F. M., Li, Y., Clarisse, L., Hurtmans, D. R., Van Damme, M., Clerbaux, C., Coheur, P.-F., Philip, S., Martin, R. V., and Pye, H. 
O. T.: Atmospheric ammonia and particulate inorganic nitrogen over the United States, Atmos. Chem. Phys., 12, 10295-10312, doi:10.5194/acp-12-10295-2012, 2012.

Henze, D. K., Seinfeld, J. H., Ng, N. L., Kroll, J. H., Fu, T.-M., Jacob, D. J., and Heald, C. L.: Global modeling of secondary organic aerosol formation from aromatic hydrocarbons: highvs. low-yield pathways, Atmos. Chem. Phys., 8, 2405-2420, doi:10.5194/acp-8-2405-2008, 2008.

Holben, B. N., Eck, T. F., Slutsker, I., Tanré, D., Buis, J. P., Setzer, A., Vermote, E., Reagan, J. A., Kaufman, Y. J., Nakajima, T., Lavenu, F., Jankowiak, I., and Smirnov, A.: AERONET - A Federated Instrument Network and Data Archive for Aerosol Characterization, Remote Sens. Environ., 66, 1-16, 1998.

Hoyle, C. R., Boy, M., Donahue, N. M., Fry, J. L., Glasius, M., Guenther, A., Hallar, A. G., Huff Hartz, K., Petters, M. D., Petäjä, T., Rosenoern, T., and Sullivan, A. P.: A review of the anthropogenic influence on biogenic secondary organic aerosol, Atmos. Chem. Phys., 11, 321-343, doi:10.5194/acp-11-321-2011, 2011.

Hudman, R. C., Jacob, D. J., Turquety, S., Leibensperger, E. M., Murray, L. T., Wu, S., Gilliland, A. B., Avery, M., Bertram, T. H., Brune, W., Cohen, R. C., Dibb, J. E., Flocke, F. M., Fried, A., Holloway, J., Neuman, J. A., Orville, R., Perring, A., Ren, X., Sachse, G. W., Singh, H. B., Swanson, A., and Wooldridge, P. J.: Surface and lightning sources of nitrogen oxides over the United States: Magnitudes, chemical evolution, and outflow, J. Geophys. Res., 112, D12S05, doi:10.1029/2006JD007912, 2007.

Hudman, R. C., Murray, L. T., Jacob, D. J., Millet, D. B., Turquety, S., Wu, S., Blake, D. R., Goldstein, A. H., Holloway, J., and Sachse, G. W.: Biogenic versus anthropogenic sources of CO in the United States, Geophys. Res. Lett., 35, L04801, doi:10.1029/2007GL032393, 2008.

Hunt, W. H., Winker, D. M., Vaughan, M. A., Powell, K. A., Lucker, P. L., and Weimer, C.: CALIPSO Lidar Description and Performance Assessment, J. Atmos. Ocean. Tech., 26, 1214-1228, 2009.

Jaeglé, L., Quinn, P. K., Bates, T. S., Alexander, B., and Lin, J.-T.: Global distribution of sea salt aerosols: new constraints from in situ and remote sensing observations, Atmos. Chem. Phys., 11, 3137-3157, doi:10.5194/acp-11-3137-2011, 2011.

Koepke, P., Hess, M., Schult, I., and Shettle, E. P.: Global Aerosol Data Set, Max-Planck-Institut für Meteorologie, Hamburg, 1997.

Leibensperger, E. M., Mickley, L. J., Jacob, D. J., Chen, W.-T., Seinfeld, J. H., Nenes, A., Adams, P. J., Streets, D. G., Kumar, N., and Rind, D.: Climatic effects of 1950-2050 changes in US anthropogenic aerosols - Part 2: Climate response, Atmos. Chem. Phys., 12, 3349-3362, doi:10.5194/acp-12-3349-2012, 2012.

Levin, E. J. T., Kreidenweis, S. M., McMeeking, G. R., Carrico, C. M., Collet Jr., J. L., and Malm, W. C.: Aerosol physical, chemical and optical properties during the Rocky Mountain Airborne Nitrogen and Sulfur study, Atmos. Environ., 43, 1932-1939.

Levin, E. J. T., McMeeking, G. R., Carrico, C. M., Mack, L. E., Kreidenweis, S. M., Wold, C. E., Moosmüller, Arnott, W. P., Hao, W. M., Collet Jr., J. L., and Malm, W. C.: Biomass burning smoke aerosol poperties measured during Fire Laboratory at Missoula Experiments (FLAME), J. Geophys. Res., 115, D18210, doi:10.1029/2009JD013601, 2010.

Lim, H.-J. and Turpin, B. J.: Origins of Primary and Secondary Organic Aerosol in Atlanta:? Results of Time-Resolved Measurements during the Atlanta Supersite Experiment, Environ. Sci.
Technol., 36, 4489-4496, 2002.

Liu, H., Jacob, D. J., Bey, I., and Yantosca, R. M.: Constraints from $210 \mathrm{~Pb}$ and $7 \mathrm{Be}$ on wet deposition and transport in a global threedimensional chemical tracer model driven by assimilated meteorological fields, J. Geophys. Res., 106, 12109-12128, 2001.

Malm, W. C. and Hand, J. L.: An examination of the physical and optical properties of aerosols collected in the IMPROVE program, Atmos. Environ., 41, 3407-3427, 2007.

Malm, W. C., Sisler, J. F., Huffman, D., Eldred, R. A., and Cahill, T. A.: Spatial and seasonal trends in particle concentration and optical extinction in the United States, J. Geophys. Res., 99, 13471370, 1994.

Mamouri, R. E., Amiridis, V., Papayannis, A., Giannakaki, E., Tsaknakis, G., and Balis, D. S.: Validation of CALIPSO spaceborne-derived attenuated backscatter coefficient profiles using a ground-based lidar in Athens, Greeces, Atmos. Meas. Tech., 2, 513-522, doi:10.5194/amt-2-513-2009, 2009.

Marsik, F. J., Fischer, K. W., McDonald, T. D., and Samson, P. J.: Comparison of Methods for Estimating Mixing Height Used during the 1992 Atlanta Field Intensive, J. Appl. Meteorol., 38, 1802-1814, 1995.

Martin, R. V., Jacob, D. J., Yantosca, R. M., Chin, M., and Ginoux, P.: Global and regional decreases in tropospheric oxidants from photochemical effects of aerosols, J. Geophys. Res., 108, 4097, doi:10.1029/2002JD002622, 2003.

Martonchik, J. V., Kahn, R. A., and Diner, D. J.: Retrieval of aerosol properties over land using MISR observations, in: Satellite Aerosol Remote Sensing Over Land, edited by: Kokhanovsky, A. A. and de Leeuw, G., Springer Praxis, Berlin, 267-291, 2009.

Mona, L., Pappalardo, G., Amodeo, A., D’Amico, G., Madonna, F., Boselli, A., Giunta, A., Russo, F., and Cuomo, V.: One year of CNR-IMAA multi-wavelength Raman lidar measurements in coincidence with CALIPSO overpasses: Level 1 products comparison, Atmos. Chem. Phys., 9, 7213-7228, doi:10.5194/acp-97213-2009, 2009.

Omar, A. H., Won, J.-G., Winker, D., M., Yoon, S.-C., Dubovik, O., and McCormick, M. P.: Development of global aerosol models using cluster analysis of Aerosol Robotic Network (AERONET) measurements, J. Geophys. Res., 110, D10S14, doi:10.1029/2004JD004874, 2005.

Omar, A. H., Winker, D. M., Vaughan, M. A., Hu, Y., Trepte, C. R., Ferrare, R. A., Lee, K.-P., Hostetler, C. A., Kittaka, C., Rogers, R. R., Kuehn, R. E., and Liu, Z.: The CALIPSO Automated Aerosol Classification and Lidar Ratio Selection Algorithm, J. Atmos. Ocean. Tech., 26, 1994-2014, 2009.

Paciorek, C. J. and Liu, Y.: Limitatinons of Remotely Sensed Aerosol as a Spatial Proxy for Fine Particulate Matter, Environ. Health Perspect., 117, 904-909, 2009.

Park, R. J., Jacob, D. J., Chin, M., and Martin, R. V.: Sources of carbonaceous aerosols over the United States and implications for natural visibility, J. Geophys. Res., 108, 2002-3190, 2003.

Park, R. J., Jacob, D. J., Field, B. D., Yantosca, R. M., and Chin, M.: Natural and transboundary pollution influences on sulfate-nitrate-ammonium aerosols in the United States: Implications for policy, J. Geophys. Res., 109, D15204, doi:10.1029/2003JD004473, 2004.

Peltier, R. E., Sullivan, A. P., Weber, R. J., Wollny, A. G., Holloway, J. S., Brock, C. A., de Gouw, J. A., and Atlas, E. L.: No evidence for acid-catalyzed secondary organic aerosol formation in power 
plant plumes over metropolitan Atlanta, Georgia, Geophys. Res. Lett., 34, L06801, doi:10.1029/2006GL028780, 2007.

Petters, M. D. and Kreidenweis, S. M.: A single parameter representation of hygroscopic growth and cloud condensation nucleus activity, Atmos. Chem. Phys., 7, 1961-1971, doi:10.5194/acp-71961-2007, 2007.

Pierce, J. R., Evans, M. J., Scott, C. E., D’Andrea, S. D., Farmer, D. K., Swietlicki, E., and Spracklen, D. V.: Weak global sensitivity of cloud condensation nuclei and the aerosol indirect effect to Criegee $+\mathrm{SO}_{2}$ chemistry, Atmos. Chem. Phys., 13, 3163-3176, doi:10.5194/acp-13-3163-2013, 2013.

Portmann, R. W., Solomon, S., and Hegerl, G. C.: Spatial and seasonal patterns in climate change, temperatures, and precipitation across the United States, PNAS, 106, 7324-7329, 2009.

Remer, L. A., Tanré, D., Kaufman, Y. J., Ichoku, C., Mattoo, S., Levy, R., Chu, D. A., Holben, B., Dubovik, O., Smirnov, A., Martins, J. V., Li, R.-R., and Ahmad, Z.: Validation of MODIS aerosol retrieval over ocean, Geophys. Res. Lett., 29, 8008, doi:10.1029/2001GL013204, 2002.

Remer, L. A., Kaufman, Y. J., Tanré, D., Mattoo, S., Chu, D. A., Martins, J. V., Li, R.-R., Ichoku, C., Levy, R. C., Kleidman, R. G., Eck, T. F., Vermote, E., and Holben B. N.: The MODIS aerosol alogrithm, products, and validation, J. Atmos. Sci., 62, 947-973, 2005.

Ridley, D. A., Heald, C. L., and Ford, B.: North African dust export and deposition: A satellite and model perspective, J. Geophys. Res., 117, D02202, doi:10.1029/2011JD016794, 2012.

Rogers, R. R., Hostetler, C. A., Hair, J. W., Ferrare, R. A., Liu, Z., Obland, M. D., Haper, D. B., Cook, A. L., Powell, K. A., Vaughan, M. A., and Winker, D. M.: Assessment of the CALIPSO Lidar $532 \mathrm{~nm}$ attenuated backscatter calibration using the NASA LaRC airborne High Spectral Resoultion Lidar, Atmos. Chem. Phys., 11, 1295-1311, doi:10.5194/acp-11-12952011, 2011.

Roy, B., Mathur, R., Gilliland, A. B., and Howard, S. C.: A comparison of CMAQ-based aerosol properties with IMPROVE, MODIS, and AERONET data, J. Geophys. Res., 112, D14301, doi:10.1029/2006JD008085, 2007.

Sheridan, P. J., Andrews, E., Ogren, J. A., Tackett, J. L., and Winker, D. M.: Vertical profiles of aerosol optical properties over central Illinois and comparison with surface and satellite measurements, Atmos. Chem. Phys., 12, 11695-11721, doi:10.5194/acp12-11695-2012, 2012.

Simon, H., Bhave, P. V., Swall, J. L., Frank, N. H., and Malm, W. C.: Determining the spatial ans seasonal variability in OM/OC ratios across the US using multiple linear regression, Atmos. Chem. Phys., 11, 2933-2949, doi:10.5194/acp-11-2933-2011, 2011.

Sorooshian, A., Lu, M.-L., Brechtel, F. J., Honsson, H., Feingold, G., Flagan, R. C., and Seinfeld, J. H.: On the source of organic acid aerosol layers above clouds. Environ. Sci. Technol., 41, 4647-4654, 2007.

Stanier, C. O., Khlystov, A. Y., and Pandis, S. N.: Ambient aerosol size distributions ans number concentrations measured during the Pittsburgh Air Quality Study (PAQS), Atmos. Environ., 38, 3275-3284, 2004.

Stephens, G. L., Vane, D. G., Boain, R. J., Mace, G. G., Sassen, K., Wang, Z., Illingworth, A. J., O'Connor, E. J., Rossow, W. B., Durden, S. L., Miller, S. D., Austin, R. T., Benedetti, A., Mitrescu, C., and Cloudsat Science Team: The CLOUDSAT Mis- sion and the A-Train, B. Am. Meteorol. Soc., 83, 1771-1790, 2002.

Stephens, G. L., Vane, D. G., Tanelli, S., Im, E., Durden, S., Rokey, M., Reinke, D., Partain, P., Mace, G. G., Austin, R., L'Ecuyer, T., Haynes, J., Lebsock, M., Suzuki, K., Waliser, D., Wu, D., Kay, J., Gettelman, A., Wang, Z., and Marchand, R.: CloudSat mission: Performance and early science after the first year of operation, J. Geophys. Res., 113, D00A18, doi:10.1029/2008JD009982, 2008.

Tegen, I. and Lacis, A. A.: Modeling of particle size distribution and its influence on the radiative properties of mineral dust aerosol, J. Geophys. Res., 101, 19237-19244, 1996.

Tian, D., Hu, Y., Wang, Y., Boylan, J. W., Zheng, M., and Russell, A. G.: Assessment of biomass burning emissions and their impacts on urban and regional PM2.5: a Georgia case study, Environ. Sci. Technol., 43, 299-305, 2009.

van der Werf, G. R., Randerson, J. T., Giglio, L., Collatz, G. J., Kasibhatla, P. S., and Arellano Jr., A. F.: Interannual variability in global biomass burning emissions from 1997 to 2004, Atmos. Chem. Phys., 6, 3423-3441, doi:10.5194/acp-6-3423-2006, 2006.

van Donkelaar, A., Martin, R. V., and Park, R. J.: Estimating ground-level $\mathrm{PM}_{2.5}$ using aerosol optical depth determined from satellite remote sensing, J. Geophys. Res., 111, D21201, doi:10.1029/2005JD006996, 2006.

van Donkelaar, A., Martin, R. V., Brauer, M., Kahn, R., Levy, R., Verduzco, C., and Villeneuve, P. J.: Global estimates of ambient fine particulate matter concentrations from satellitebased aerosol optical depth: development and application, Environ. Health Perspect., 118, 847-855, doi: 10.1289/ehp.0901623, 2010.

Volkamer, R., Jimenez, J. L., Martini, F. S., Dzepina, K., Zhang, Q., Salcedo, D., Molina, L. T., Worsnop, D. R., and Molina, M. J.: Secondary organic aerosol formation from anthropogenic air pollution: Rapid and higher than expected, Geophys. Res. Lett., 33, L17811, doi:10.1029/2006GL026899, 2006.

Wang, Y., Jacob, D. J., and Logan, J. A.: Global simulation of tropospheric O3-NO x -hydrocarbon chemistry 3, Origin of tropospheric ozone and effects of nonmethane hydrocarbons, J. Geophys. Res., 103, 10757-10767, 1998.

Weber, R. J., Bergin, M., Kiang, C. S., Chameides, W., Orsini, D., St, J. J., Chang, M., Bergin, M., Carrico, C., Lee, Y. N., Dasqupta, P., Slanina, J., Turpin, B., Edgerton, E., Hering, S., Allen, G., and Solomon, P.: Short-term temporal variation in PM2.5 mass and chemical composition during the Atlanta Supersite Experiment, 1999, J. Air Waste Manag. Assoc., 53, 84-91, 2003.

Weber, R. J., Sullivan, A. P., Peltier, R. E., Russell, A., Yan, B., Zheng, M., Gouw, J. de, Warneke, C., Brock, C., Holloway, J. S., Atlas, E. L., and Edgerton, E.: A study of secondary organic aerosol formation in the anthropogenicinfluenced southeastern United States, J. Geophys. Res., 112, D13302, doi:10.1029/2007JD008408, 2007.

Wesely, M. L.: Parameterization of surface resistances to gaseous dry deposition in regional-scale numerical models, Atmos. Environ., 23, 1293-1304, 1989.

Winker, D. M.: The CALIPSO mission: spaceborne lidar for observation of aerosols and clouds, SPIE, 4893, 1-11, 2003.

Winker, D. M., Vaughan, M. A., Omar, A., Hu, Y., Powell, K. A., Liu, Z., Hunt, W. H., and Young, S. A.: Overview of the 
CALIPSO Mission and CALIOP Data Processing Algorithms, J. Atmos. Ocean. Tech., 26, 2310-2323, 2009.

Winker, D. M., Tackett, J. L., Getzewich, B. J., Liu, Z., Vaughan, M. A., and Rogers, R. R.: The global 3-D distribution of tropospheric aerosols as characterized by CALIOP, Atmos. Chem. Phys., 13, 3345-3361, doi:10.5194/acp-13-3345-2013, 2013.

Yan, B., Zheng, M., Hu, Y., Ding, X., Sullivan, A. P., Weber, R. J., Baek, J., Edgerton, E. S., and Russell, A. G.: Roadside, urban, and rural comparison of primary and secondary organic molecular markers in ambient PM2.5, Environ. Sci. Technol., 43, 42874293, 2009.

Young, S. A. and Vaughan, M. A.: The retrieval of profiles of particulate extinction from Cloud-Aerosol Lidr and Infrared Pathfinder Satellite Observations (CALIPSO) data: Algorithm ddescription, J. Atmos. Ocean. Tech., 26, 1105-1119, 2009.

Young, S. A., Vaughan, M. A., Kuehn, R. E., and Winker, D.M.: The retrieval of profiles of particulate extinction from Cloud-Aerosol Lidr and Infrared Pathfinder Satellite Observations (CALIPSO) data: Uncertainity and error sensitivity analyses, J. Atmos. Ocean. Tech., 12, 395-428, doi:10.1175/JTECH-D-12-00046.1, 2013.

Zeng, T., Wang, Y., Yoshida, Y., Tian, D., Russell, A. G., and Barnard, W. R.: Impacts of prescribed fires on air quality over the Southeastern United States in spring based on modeling and ground/satellite measurements, Environ. Sci. Technol., 42, 84018406, 2008.

Zhang, H., Hoff, R. M., and Engel-Cox, J. A.: The relation between Moderate Resolution Imaging Spectroradiometer (MODIS) aerosol optical depth and $\mathrm{PM}_{2.5}$ over the United States: a geographical comparison by U.S. Environmental Protection Agency regions, J. Air Waste Manag. Assoc., 59, 13581369, 2009.
Zhang, L., Jacob, D. J., Knipping, E. M., Kumar, N., Munger, J. W., Carouge, C. C., van Donkelaar, A., Wang, Y. X., and Chen, D.: Nitrogen deposition to the United States: distribution, sources, and processes, Atmos. Chem. Phys., 12, 4539-4554, doi:10.5194/acp-12-4539-2012, 2012 b.

Zhang, L., Vet, R., Wiebe, A., Mihele, C., Sukloff, B., Chan, E., Moran, M. D., and Iqbal, S.: Characterization of the sizesegregated water-soluble inorganic ions at eight Canadian rural sites, Atmos. Chem. Phys., 8, 7133-7151, doi:10.5194/acp-87133-2008, 2008.

Zhang, X., Hecobian, A., Zheng, M., Frank, N. H., and Weber, R. J.: Biomass burning impact on $\mathrm{PM}_{2.5}$ over the southeastern US during 2007: integrating chemically speciated FRM filter measurements, MODIS fire counts and PMF analysis, Atmos. Chem. Phys., 10, 6839-6853, doi:10.5194/acp-10-6839-2010, 2010.

Zhang, X., Liu, Z., Hecobian, A., Zheng, M., Frank, N. H., Edgerton, E. S., and Weber, R. J.: Spatial and seasonal variations of fine particle water-soluble organic carbon (WSOC) over the southeastern United States: implications for secondary organic aerosol formation, Atmos. Chem. Phys., 12, 6593-6607, doi:10.5194/acp-12-6593-2012, 2012a.

Zheng, M., Cass, G. R., Schauer, J. J., and Edgerton, E. S.: Source Apportionment of $\mathrm{PM}_{2.5}$ in the Southeastern United States Using Solvent-Extractable Organic Compounds as Tracers, Environ. Sci. Technol., 36, 2361-2371, 2002. 